\title{
PROBLEMATIKA KEBIJAKAN PENDIDIKAN DI TENGAH PANDEMI DAN DAMPAKNYA TERHADAP PROSES PEMBELAJARAN DI SEKOLAH DASAR
}

\author{
Syariful Anam \\ Elya Umi Hanik \\ PGMI IAIN Kudus, Indonesia \\ anamsyariful398@gmail.com \\ elyaumi@iainkudus.ac.id
}

\begin{abstract}
Abstrak
Pandemi covid telah merubah seluruh tatanan kehidupan manusia, khususnya di dunia Pendidikan. Hal tersebut mengharuskan pendidikan berubah dan beradaptasi secara cepat untuk tetap melanjutkan proses pembelajaran. Tujuan dari artikel ini untuk meninjau dampak dampak yang ditimbukan kebijakan menteri Pendidikan dan Kebudayaan Republik Indonesia tentang Work From Home (WFH) di dunia pendidikan terutama di kalangan sekolah dasar. Artikel ini ditulis dengan meninjau artikel artikel dan referensi terkait tentang kebijakan pembelajaran online yang dianggap sebagai solusi untuk tetap melanjutkan proses pembelajaran ketika sekolah sekolah ditutup untuk menghindari penyebaran virus. Namun, dilain sisi kebijakan tersebut telah memberikan dampak terhadap proses tranformasi ilmu pengetahuan baik terhadap peserta didik, guru maupun orang tua atau keluarga. Penelitian ini menggunakan metode kualitatif yang berbasis library resert (keperpustakaan).
\end{abstract}

Kata kunci : Kebijakan, Pandemi Covid-19, Proses Pembelajaran.

\section{Abstract}

The Covid pandemic has changed the entire order of human life, especially in the world of education. This requires education to change and adapt quickly to continue the learning process. The purpose of this article is to examine the impact of the Ministry of Education and Culture of the Republic of Indonesia policy on Work From Home (WFH) in education, especially among elementary schools. This article was written by reviewing articles and related references about online learning policies that are considered a solution to continue the learning process when schools are closed to avoid spreading the virus. However, on the other hand, this policy has had an impact on the process of transforming knowledge both for students, teachers and parents or families. This study uses a qualitative method based on library research (libraries).

Keywords: Policy, Covid-19 Pandemic, Learning Process. 


\section{A. PENDAhuluan}

Pandemi Covid-19 mempengaruhi banyak hal dan kemudian membentuk sebuah tatanan hal baru. Pandemi ini pula bagaikan memberikan jalan baru kepada sebuah transformasi baru dalam kehidupan. Hal tersebut pula yang menuntut kehidupan untuk berubah dalam kurun waktu yang cepat. Tuntutan peralihan tersebut yang telah menjamah begitu luas sektor kehidupan, maka pendidikan pula tak lepas dari arus tersebut. Itulah yang kemudian menuntut para pamangku kebijakan sebagai pengayom dan pemberi keputusan atas keberlangsungan dan ketertiban kehidupan telah mengeluarkan kebijakan-kebijakan yang berkaitan dengan pandemic. ${ }^{1}$

Banyak pula Negara yang mengambil kebijakan dengan melakukan penutupan sekolah sebagai langkah menyelamatkan pendidikan dari hantaman bahaya virus, tak terkecuali Indonesia. Penutupan lembaga pendidikan tersebut kemudian bermuara pada kebijakan belajar dari rumah, mengajar dari rumah, atau bekerja dari rumah. Semuanya serba dirumahkan, yang secara otomatis penggunaan media atau ruang akan berganti pula dari offline menuju ke serba online.

Dengan diberlakukannya pembelajaran secara daring yang di galakkan oleh pemerintah, memunculkan berbagai respon dari peserta didik dalam melakukan pembelajaran di rumah secara daring, respon tersebut ada yang bersifat positif dan ada juga yang bersifat negatif, siswa diharapkan mampu melakukan proses pembelajaran secara daring ini untuk menjalankan proses pembelajaran agar tidak tertinggal, dalam proses pembelajaran daring memunculkan berbagai macam prilaku-prilaku dari peserta didik, prilaku-prilaku tersebut dapat mencerminkan apakah peserta didik mampu beradaptasi dengan proses pembelajaran yang baru ataukah peserta didik tersebut tidak mempu dalam menjalankan proses pembelajaran yang dilakukan secara daring. ${ }^{2}$

Kebijakan peralihan media pembelajaran ini kepada pembelajaran dalam jaringan yang dilakukan secara online kemudian memberikan berbagai macam problematika di dunia Pendidikan terutama terhadap Pendidikan di sekolah dasar. Proses belajar dari rumah merupakan hal yang baru bagi sebahagian keluarga di Indonesia, itu merupakan kejutan besar khususnya bagi produktivitas orang tua yang biasanya sibuk dengan pekerjaannya di luar rumah. Bukan hanya bagi keluarga, tetapi juga berdampak pada kondisi psikologi peserta didik SD yang biasanya bertatapan langsung namun tiba-tiba harus serba online.

Namun, pada kenyataan sangat sedikit pelajar yang memanfaatkan pada sisi ini, smartphone yang mereka miliki umumnya digunakan untuk main game, mendengarkan musik, menonton video, mengakses faceebok, memfungsikan internet tidak pada fungsinya. Selanjutnya ini akan berdampak pada proses dan prestasi belajarnya. Prilaku

\footnotetext{
${ }^{1}$ Muchammad Bayu Tejo S, dkk. 2020. Budaya Media Sosial, Edukasi Masyarakat dan Pandemi COVID19. Jurnal Sosial \& Budaya Syar-i FSH UIN Hidayatullah Jakarta

${ }^{2}$ Mustakim, (2020). Efektifitas Pembelajaran Daring Menggunakan Media Online Selama Pandemi Covid19 pada Mata Pelajaran Matematika. Al asma: Jurnal Of Islamic Education Vol.2, No.1
}

74 | Syariful Anam dan Elya Umi H: Problematika Kebijakkan Pendidikan, .... 
ini sangat berpengaruh terhadap proses belajar mengajar siswa yang dilakukan secara daring. Siswa yang seharusnya mengikuti proses pembelajaran daring dengan menggunakan smartphone, sebaliknya siswa malah menggunakan smartphone tersebut untuk kepentingan pribadinya. Dari masalah ini penulis mengambil judul Problematika Kebijakan Pendidikan Di Tengah Pandemi Dan Dampaknya Terhadap Proses Pembelajaran Di Sekolah Dasar. ${ }^{3}$ Tujuannya untuk mengetahui Dampak kebijakan pemerintah terhadap siswa SD/MI dalam pembelajaran daring di masa pandemi seperti sekarang ini. ${ }^{4}$

\section{B. METODE PENELITIAN}

Penelitian ini menggunakan metode penelitian kualitatif yang berbasis kepustakaan. Dimana penelitian ini dalam pengumpulan informasi serta data-datanya menggunakan berbagai macam bahan dan materi, seperti buku, jurnal-jurnal terkait, serta sumber yang memiliki reverensi lainnya. Dengan metode ini diharapkan dapat mengidentifikasi Problematika Kebijakan Pemerintah dimasa pandemic dan dampaknya terhadap pembelajaran di Pendidikan SD/MI.

\section{PEMBAHASAN DAN TEMUAN}

\section{Kebijakan Pemerintah di Era Pandemi}

Istilah kebijakan merupakan terjemahan dari kata bahasa Inggris "Policy" yang dibedakan dari kata kebijaksanaan (Wisdom) maupun kebajikan (virtues). Menurut Irfan Islamy (1999), kebijaksanaan berasal dari kata"Wisdom"adalah tindakan yang memerlukan pertimbangan-pertimbangan yang lebih $j$ auhdan mendalam. Sementara kebijakan adalah tindakan mencakup aturan-aturan yang terdapat didalam suatu kebijaksanaan. M.Solly Lubis (2007 ) mengatakan Wisdom dalam arti kebijaksanaan atau kearifan adalah pemikiran/pertimbangan yang mendalam untuk menjadi dasar (landasan) bagi perumusan kebijakan. Kebijakan (policy) adalah seperangkat keputusan yang diambil oleh pelaku-pelaku politik dalam rangka memilih tujuan dan cara untuk pencapaian tujuan ${ }^{5}$.

Karakter virus Corona sangat berbeda dengan jenis penyakit epidemik lainnya seperti kolera, pes, influenza, flu burung, dan lain-lain. COVID-19 ini sangat menyiksa manusia. Jika dia sudah menjangkiti orang, bukan hanya orang/warga/pasien yang terinfeksi Corona yang diisolasi oleh pemerintah, tetapi seluruh warga masyarakat akan turut diisolasi, baik warga yang sakit maupun warga yang sehat. Tempat karantina di

\footnotetext{
${ }^{3}$ Nikmah, Astin. 2013. Dampak Penggunaan Handphone Terhadap Prestasi Siswa. E-Jurnal Dinas Pendidikan Kota Surabaya: Volume 5

${ }^{4}$ Oktafia Ika Handarini, Siti Sri Wulandari. 2020. Pembelajaran Daring sebagai Upaya Study From Home (SFH) Selama Pandemi Covid 19. Jurnal Pendidikan administrasi Perkantoran (JPAP). Volume 8, Nomor 3, 2020.

${ }^{5}$ Dr. Taufiqurokhman, S.Sos,M.Pd Kebijakan Publik Pendelegasian Tanggung Jawab Negara Kepada Presiden Selaku Tanggung Jawab Pemerintah, Fakultas Ilmu Sosial dan Ilmu Politik Moestopo Beragama Pers, HIm. 9
} 
rumah sakit bagi yang sudah terinfeksi, sementara yang sehat, akan dikarantina di rumah masing-masing secara mandiri. Isolasi mandiri dilakukan untuk mencegah dan menghindari penyebaran virus Corona meluas ke masyarakat. Namun, pandemi COVID-19 membuat hampir semua orang kalang-kabut menghadapinya. Persoalan menjadi sangat serius karena yang dihadapi adalah ketidakpastian baru. Pandemi Covid19 menjadi disrupsi sehingga kita perlu mengenali, mengatasi, dan mencegahnya agar ketidakpastian ini segera berakhir (Satria, 2020). ${ }^{6}$

Untuk mencegah penyebaran dan penularan virus Corona menyebar luas ke dalam masyarakat, pemerintah membuat serangkain kebijakan untuk menanganinya. Kebijakan yang dibuat oleh pemerintah tersebut ada yang tertulis, dan ada pula yang tidak tertulis. Kebijakan yang tertulis bentuknya misalnya seperti Undang-Undang (UU), Peraturan Pemerintah Pengganti Undang-Undang (PERPU), Peraturan Pemerintah (PP), Peraturan Presiden (PERPRES), Peraturan Menteri (PERMEN), Peraturan Daerah (PERDA), Peraturan Bupati (PERBUP), Peraturan Walikota (PERWALI), dan lain-lain termasuk di dalamnya adalah Surat Keputusan (SK), dan Surat yang berasal dari pemerintah.

Sedangkan kebijakan yang tidak tertulis bentuknya adalah ajakan tidak tertulis yang berasal dari pemerintah, tokoh masyarakat, tokoh adat, tokoh budaya, tokoh agama, yang berisi larangan dan himbauan terkait dengan pencegahan dan penanganan COVID -19. Contoh kebijakan tertulis seperti: KEPPRES No. 11/2020 tentang Penetapan Kedaruratan Kesehatan Masyarakat Corona Virus Disease 2019 (COVID19), PERPU Nomor 1 Tahun 2020 Tentang Kebijakan Keuangan Negara dan Stabilitas Sistem Keuangan untuk Penanganan Pandemi Corona Virus Disease 2019 (COVID-19) dan/atau dalam rangka Menghadapi Ancaman yang Membahayakan Perekonomian Nasional dan/atau Stabilitas Sistem Keuangan; PP Nomor 21 Tahun 2020 Tentang Pembatasan Sosial Berskala Besar Dalam Rangka Percepatan Penanganan Corona Virus Disease 2019 (COVID-19), Surat Edaran No. 57/2020 Tanggal 28 Mei 2020 Tentang Perpanjangan Pelaksanaan Kerja dari Rumah/Work From Home (WFH) bagi Aparatur Sipil Negara (ASN) hingga 4 Juni 2020; Keputusan Presiden (KEPPRES) No. 12 Tahun 2020 tentang Penetapan Bencana Nonalam Penyebaran Corona Virus Disease 2019 (COVID-19) Sebagai Bencana Nasional, dan lain-lain. ${ }^{7}$

${ }^{6}$ Keputusan Presiden (KEPPRES) No. 12 Tahun 2020 tentang Penetapan Bencana Nonalam Penyebaran Corona Virus Disease 2019 (COVID-19) Sebagai Bencana Nasional

7 Keputusan Presiden (KEPPRES) No. 12 Tahun 2020 tentang Penetapan Bencana Nonalam Penyebaran Corona Virus Disease 2019 (COVID-19) Sebagai Bencana Nasional

76 | Syariful Anam dan Elya Umi H: Problematika Kebijakkan Pendidikan, .... 


\section{Problematika Kebijakan Pemerintah di Era Pandemi}

Di era pandemi COVID-19 ini tentunya tidak memungkinkan untuk menerapkan pembelajaran dilaksanakan secara face to face atau secara langsung mungkin setidaknya bisa dilakukan dengan jarak jauh atau virtual yaitu pembelajaran secara online dengan melakukan live e-learning melalui berbagai platform aplikasi yang tersedia seperti Zoom, Google Meet, Google Classroom yang merupakan media berbasis aplikasi yang dapat dioptimalkan untuk wadah pembelajaran. Melalui media aplikasi elektronik tersebut tenaga pendidik juga dapat mentransfer pengetahuan dan keterampilan seperti biasanya saat melakukan pembelajaran secara face to face atau langsung.Dalam pembelajaran jarak jauh atau online ini juga tetap bisa membangun karakter peserta didik misalnya saja dapat dilihat dengan disiplin waktu dalam memulai dan mengakhiri pertemuan kelas daring atau online, disiplin waktu batas waktu upload tugas, kemandirian melalui tugas individu, kerjasama melalui tugas kelompok dan etika dalam berbicara atau menulis saat live e-learning berlangsung antara peserta didik dengan tenaga pendidik. ${ }^{8}$

Peran tenaga pendidik tentu tidak tergantikan oleh mesin. Tetapi kemampuan tenaga pendidik menyentuh pada aspek rasa, bahasa dan pembentuk karakter menjadikan kehadirannya selalu ditunggu oleh peserta didik, kapan dan dimanapun teknologi tentu diciptakan untuk memudahkan pekerjaan manusia, termasuk dalam proses belajar. Perpaduan kedua hal ini merupakan solusi yang tepat dalam belajar di era ini dan khususnya saat penerapan kebijakan new normal saat ini. Saat ini proses pembelajaran tergantung kepada peserta didik dalam memahami materi dalam lingkup kelas jarak jauh atau online ini. hal ini tentunya perlu sekali di perhatikan pemerintah dalam kebijakan dalam hal mengevaluasi pendidikan di masa new normal. ${ }^{9}$

Kurikulum pendidikan juga disesuaikan dengan pandemi sekarang ini. Bisa dimulai dengan protokol kesehatan dengan menerapkan tetap menjaga jarak agar tidak terlalu berdekatan.Para tenaga pendidik dan peserta didik juga tentunya dengan diterapkannya protokol kesehatan tentu akan merasa sedikit tenang dan aman saat proses belajar mengajar dilaksanakan. Wali murid atau orang tua murid di rumah saya rasa juga akan setuju apabila pembelajaran sudah dilakukan secara face to face langsung dengan adanya penerapan.

\section{Dampak dari Kebijakan Pemerintah Terhadap Pendidikan SD/MI}

Belajar dari rumah ditetapkan melalui kebijakan yang dikeluarkan oleh Kementerian Pendidikan dan Kebudayaan Republik Indonesia melalui SE nomor 4 tahun 2020 tentang pelaksanaan pendidikan masa darurat penyebaran Corona Virus Desease 2019 (Covid-19). Dari kebijakan tersebutlah kemudian berdampak proses pembelajaran yang ada di sekolah,

\footnotetext{
${ }^{8}$ Aji, R.H.S Dampak Covid-19 Pada Pendidikan di Indonesia:Sekolah, Ketrampilan, dan Proses Pembelajaran, SALAM : Jurnal Sosial \& Budaya Syar-I, 2020 Hlm : 5

${ }^{9}$ Muyia Nafukho and Chakraborty, $M$ 'Strengthening student engagement: what do students want in online course?', European Journal of training and Development, Vol,39, No,9 Hlm 121

77 | Syariful Anam dan Elya Umi H: Problematika Kebijakkan Pendidikan, ....
} 
terutama buat peserta didik, guru, maupun orang tua atau keluarga peserta didik. Proses pembelajaran sebagai sesuatu yang dialami siswa di sekolah dasar merupakan alat kebijakan publik terbaik sebagai upaya peningkatan pengetahuan dan skill. Hal yang kemudian juga telah tertanam dalam diri sebagian besar peserta didik adalah sekolah menjadi tempat yang menyenangkan sebagai wahana bermain, berinteraksi dan membangun hubungan serta kesadaran sosial. $^{10}$

Sekolah menjadi pusat interaksi antara guru dengan peserta didik dalam meningkatkan, pengetahuan, keterampilan serta penanaman sikap dan karakter, maka hal tersebutlah yang kemudian tiba-tiba berhenti saat sekolah pun tiba-tiba ditutup. Kebijakan yang dikeluarkan tersebut sebagai upaya untuk menyelamatkan peserta didik dari bahaya virus tetapi justru pula akan menimbulkan beberapa dampak khususnya pada peserta didik, guru, dan orang tua. Peserta didik sendiri akan merasa terpaksa belajar dari rumah yang sebenarnya tidak memiliki fasilitas yang memadai untuk hal tersebut, dengan begitu maka proses pembelajaran akan terhambat yang seharusnya sebelum dimulainya pembelajaran tersebut fasilitas pendukung harus tersedia lebih dahulu.

Kemudian selanjutnya terletak pada proses adaptasi pembelajaran, peserta didik yang tadinya cenderung berinteraksi langsung dalam pembelajaran akan memerlukan berbagai macam adaptasi belajar serta memahami pembelajaran yang di modelkan dalam jaringan, sehingga kebijakan yang diberikan bisa saja menimbulkan mandeknya pemahaman peserta didik terhadap pembelajaran. Mengigat bahwa perubahan ke pembelajaran online secara tidak langsung berpengaruh terhadap daya serap peserta didik. Oleh karenanya, bahwa peserta didik harus didasari oleh berbagai pengalaman belajar agar pembelajaran secara online menjadi lebih fleksibel. ${ }^{11}$

Pokok permasalahan bagi peserta didik SD/MI tersebut bermuara pada perubahan lingkungan pembelajaran dari offline ke online sehingga dibutuhkan hal-hal yang harus menarik minat belajar online peserta didik melalui penciptaan lingkungan belajar yang positif, membangun komunitas belajar, memberikan umpan balik yang konsisten secara tepat waktu, dan menggunakan teknologi yang tepat untuk mengirimkan konten yang tepat.

Dampak selanjutnya tentu terletak pada tenaga pengajar atau guru.sebagai seorang pendidik tentunya memiliki tanggung jawab terhadap proses pembelajaran peserta didiknya, namun akibat dari pandemic covid-19 dan berlakunya kebijakan WFH maka proses pembelajaran ikut terdampak dikarenakan beberapa hal yang menjadi hambatan bagi guru untuk melakukan proses pembelajaran secara online diantaranya $:{ }^{12}$

\footnotetext{
${ }^{10}$ Purwanto, A, dkk, Studi Eksploratif Dampak Pandemi COVID-19 Terhadap Proses Pembelajaran Online di Sekolah Dasar, EdupsyCouns Journal : Journal of education, Psychology, and Conseling, 2020, Hlm 12

11 Then, Cook Klein. 2014. Adapting Early Childhood Curriculum For Children With Special Needs. USA: Pearson.

12 Brozik A and Zapalska, 'Learning styles and online Education', Campus-Wide Information System Vol.23 No.5 Hlm: 325-335
}

78 | Syariful Anam dan Elya Umi H: Problematika Kebijakkan Pendidikan, .... 


\section{1) Keterbatasan Pengetahuan Tekhnologi}

Keterbatasan penggunaan tekhnologi menjadi hambatan yang signifikan bagi proses pembelajaran yang dilakukan oleh guru, hal tersebut dikarenakan masih banyaknya guru-guru senior atau yang sudah berumur namun tidak melek terhadap penggunaan tekhnologi pembelajaran berbasis online tersebut. Sehingga seharusnya terlebih dahulu diperlukan proses pelatihan untuk para guru-guru dalam peningkatan kapasitas mengajar berbasis media online tersebut.

2) Keterbatasan Sarana dan Prasarana Fasilitas sebagai penunjang dalam proses pembelajaran tidak boleh terhambat. Keterbatasan sarana dan prasarana tentunya akan berdampak pula terhadap proses transfer pengetahuan. Dampak dari kebijakan bekerja dari rumah membuat banyaknya tenaga pendidik yang sedari awal bertatap muka langsung menyebabkan ketersediaan perangkat online tidak memadai. Sehingga seharusnya persiapan perangkat seperti laptop, jaringan, handphone harus dipersiapkan agar proses pemberian materi menjadi lebih baik.

3) Keterbatasan Pengalaman Pembelajaran Online Proses pembalajaran yang selama ini dilakukan sebelum pandemi tentunya membuat guru sangat minim dalam pembelajaran secara online. Hal tersebut akan berdampak pada proses penyampaian materi juga penyampaian pemahaman kepada peserta didik, yang berakibat pada tidak efektifnya pembelajaran. Guru yang dari awal melakukan proses tatap muka justru kemudian di paksa untuk memberikan pelajaran melalui perangkat internet. Sehingga bisa saja berdampak pada kejenuhan ataupun kebosanan guru sehingga malas untuk memberikan pembelajaran kepada peserta didiknya. Itulah yang menjadi hambatan pada guru terkait pembelajaran yang diinstruksikan oleh kebijakan menteri pendidikan tersebut. Bisa saja, seiring dengan proses adaptasi hambatan-hambatan tersebut bisa di minimalisir, namun dampak-dampak yang telah ditimbulkan akibat pandemic dengan kebijakan seperti itu disisi lain telah berpengaruh besar terhadap proses pembelajaran siswa.

Dampak selanjutnya dirasakan oleh para orang tua peserta didik. Dimulai dari dampak adanya biaya tambahan untuk menyediakan fasilitas, baik itu berupa perangkat keras semisal komputer maupun handphone atau perangkat pendukung jaringan internet berupa paket kuota. Dengan begitu, maka secara otomatis beban pengeluaran keluarga pun akan bertambah. Selanjutnya adalah para orang tua dipaksa beradaptasi dan melakukan pendampingan pembelajaran anak-anaknya, sehingga mereka harus meluangkan waktu ketika anak-anak tersebut belajar secara online, sehingga aktivitas sehari-hari ataupun pekerjaan akan terdampak pula. Namun, dibalik itu terdapat Kendala lain yang ditemukan yakni kemampuan orang tua untuk memberikan fasilitas pendidikan online mereka yang hanya berprofesi petani dan tidak melek tekhnologi tentunya akan merasa kesulitan dalam pendampingan peserta didik. 


\section{KESIMPULAN}

Dapat kita pahami bersama bahwa pandemic covid-19 telah memaksa seluruh sector untuk bertransformasi secara tiba-tiba untuk mengakimodir kegiatan-kegiatan yang berbasis offline menuju kepada online, lahirnya kebijakan KEMENDIKBUD untuk bekerja dari rumah dan belajar dari rumah menjadi salah satu upaya menjaga masyarakat dari pandemi. Namun, di satu sisi kebijakan tersebut telah berdampak banyak pada proses pendidikan baik bagi siswa, maupun guru dan juga keluarga atau orang tua.

Pokok permasalahan utama terletak pada ketidaksisapan fasilitas, pengetahuan maupun kurangnya pengalaman, sehingga dibutuhkan waktu untuk beradaptasi dan menyebabkan keterlambatan proses pembelajaran, serta perbedaan kondisi wilayah yang belum kesemuanya dapat dijangkau internet secara menyeluruh. Oleh karenanya, perlu kiranya dilakukan pembaruan model pendidikan yang sesuai dengan kondisi pandemic namun tidak menimbulkan dampak pada proses pembelajaran, misalnya melakukan pembelajaran kontekstual yang berbasis kehidupan sehari-hari peserta didik.

Solusi yang dapat penulusi tawarkan yaitu sebaiknya pemerintah jika ingin menerapkan kebijakan selama pandemi ini terhadap dunia pendidikan disesuaikan dengan tingkatan tingkan masing masing jenjang dilihat dari segi kesiapannya baik dari prasarana dan sdm yang mendukung. Selanjutnya bagi orang tua untuk lebih mengawasi anaknya dalam menggunakan

media internet dalam pembelajaran daring selama masa pandemi ini, agar anak tidak terjerumus kepada penyimpangan-penyimpangan terhadap penggunaan internet, serta bisa memaksimalkan penggunakan internet oleh anak dengan baik dan benar. 


\section{E. DAFTAR PUSTAKA}

Muchammad Bayu Tejo S, dkk. 2020. Budaya Media Sosial, Edukasi Masyarakat dan Pandemi COVID-19. Jurnal Sosial \& Budaya Syar-i FSH UIN Hidayatullah Jakarta

Mustakim. (2020). Efektifitas Pembelajaran Daring Menggunakan Media Online Selama Pandemi Covid-19 pada Mata Pelajaran Matematika. Al asma: Jurnal Of Islamic Education Vol.2, No.1

Nikmah, Astin. 2013. Dampak Penggunaan Handphone Terhadap Prestasi Siswa. E-Jurnal Dinas Pendidikan Kota Surabaya: Volume 5

Oktafia Ika Handarini, Siti Sri Wulandari. 2020. Pembelajaran Daring sebagai Upaya Study From Home (SFH) Selama Pandemi Covid 19. Jurnal Pendidikan administrasi Perkantoran (JPAP). Volume 8, Nomor 3, 2020

Taufiqurokhman. Kebijakan Publik Pendelegasian Tanggung Jawab Negara Kepada Presiden Selaku Tanggung Jawab Pemerintah, Fakultas Ilmu Sosial dan Ilmu Politik Moestopo Beragama Pers, Hlm. 9

Keputusan Presiden (KEPPRES) No. 12 Tahun 2020 tentang Penetapan Bencana Nonalam Penyebaran Corona Virus Disease 2019 (COVID-19) Sebagai Bencana Nasional

Aji, R.H.S Dampak Covid-19 Pada Pendidikan di Indonesia:Sekolah, Ketrampilan, dan Proses Pembelajaran, SALAM : Jurnal Sosial \& Budaya Syar-I, 2020 Hlm : 5

Muyia Nafukho and Chakraborty. 'Strengthening student engagement: what do students want in online course?', European Journal of training and Development, Vol,39, No,9 HIm 121

Purwanto, A, dkk. Studi Eksploratif Dampak Pandemi COVID-19 Terhadap Proses Pembelajaran Online di Sekolah Dasar, EdupsyCouns Journal : Journal of education, Psychology, and Conseling, 2020, Hlm 12

Then, Cook Klein. 2014. Adapting Early Childhood Curriculum For Children With Special Needs. USA: Pearson.

Brozik A and Zapalska. 'Learning styles and online Education', Campus-Wide Information System Vol.23 No.5 Hlm: 325-335 